\title{
Appendix to Cover Art, The Journal of Texas Archeology and History Volume 4 (2017/2018): A Visual Guide to the Archaic Points Found at the Gault Site (41BL323) with Clovis Points for Comparison
}

Thomas J. Williams

Gault School of Archeological Research, Texas State University

Follow this and additional works at: https://scholarworks.sfasu.edu/ita

Part of the American Material Culture Commons, Archaeological Anthropology Commons, Environmental Studies Commons, Other American Studies Commons, Other Arts and Humanities Commons, Other History of Art, Architecture, and Archaeology Commons, and the United States History Commons

Tell us how this article helped you.

This Article is brought to you for free and open access by the Center for Regional Heritage Research at SFA ScholarWorks. It has been accepted for inclusion in Index of Texas Archaeology: Open Access Gray Literature from the Lone Star State by an authorized editor of SFA ScholarWorks. For more information, please contact cdsscholarworks@sfasu.edu. 


\section{Appendix to Cover Art, The Journal of Texas Archeology and History Volume 4 (2017/2018): A Visual Guide to the Archaic Points Found at the Gault Site (41BL323) with Clovis Points for Comparison}

\section{Licensing Statement}

Reproduction, posting, transmission, or other distribution or use of the Journal volume, individual article or any portion of the material therein, in any medium, is permitted strictly for personal, non-commercial purposes via a personal-use exemption under a Creative Commons license granted by JTAH.org, Inc. This license exemption requires, as a condition of its granted permission, proper credit be attributed to JTAH.org as copyright holder (e.g., Journal of Texas Archeology and History.org ( $~ 2018)$. No part of this publication may be reproduced, posted, transmitted, or otherwise utilized or distributed in any form by any means or method for commercial purposes without the express written consent of the Publisher. Inquiries should be addressed to JTAH Publisher, Suite 307, Box 361, 5114 Balcones Woods Drive, Austin, Texas, 78759.

The Journal of Texas Archeology and History.org is an organization dedicated to furthering research, education and public outreach in the fields of archeology and history concerning Texas and its bordering states of Louisiana, Arkansas, Oklahoma, New Mexico and Northern Mexico; a region we call the "Texas Borderlands." The J.T.A.H. is collaborating with the Index of Texas Archaeology and S.F.A.S.U. to distribute their publication library to the general public via free and open-access channels. Visit www.JTAH.org to submit an article. 


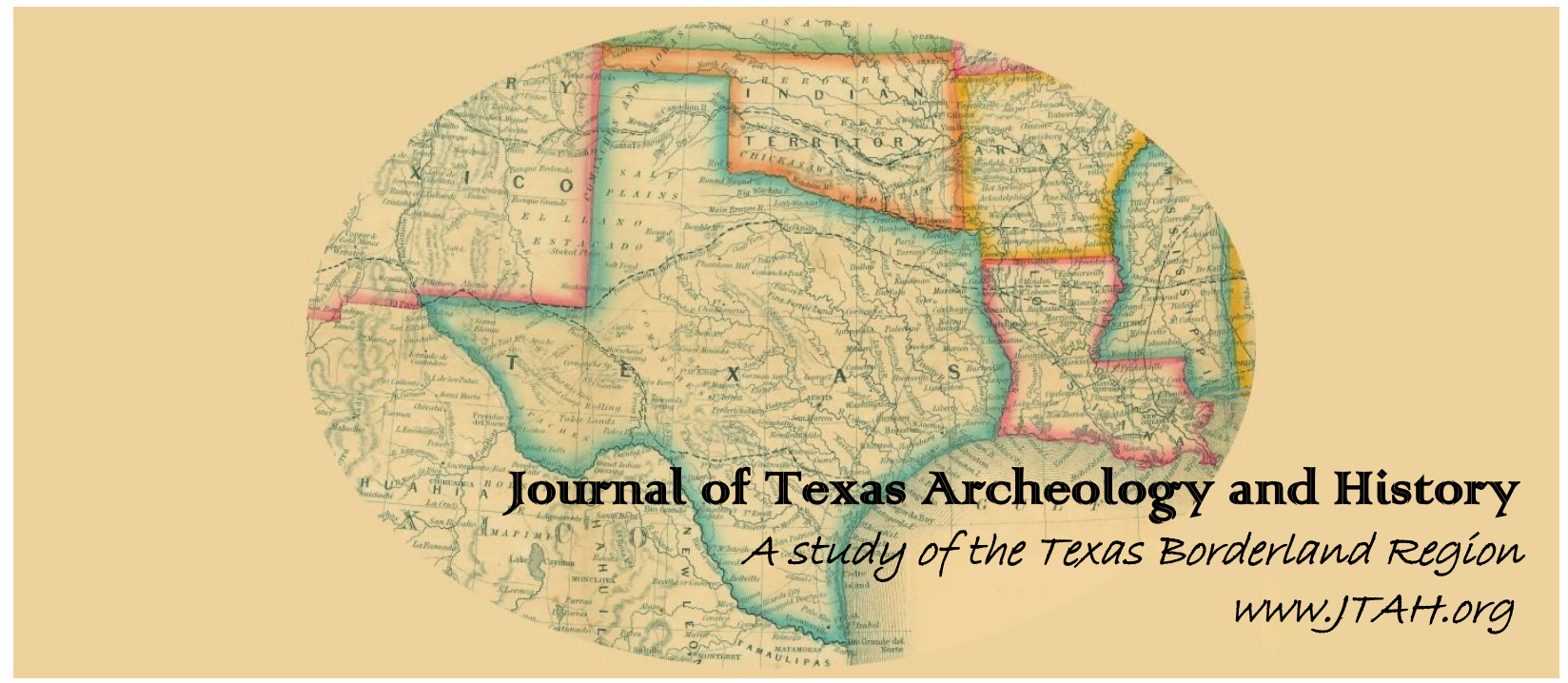

\title{
Article Title: APPENDIX TO COVER ART, THE JOURNAL OF TEXAS ARCHEOLOGY AND HISTORY Volume 4 (2017/2018): A VISUAL GUIDE TO THE ARCHAIC POINTS FOUND AT THE GAULT SITE (41BL323) WITH CLOVIS POINTS FOR COMPARISON
}

\author{
Author(s): $\quad$ Thomas J. Williams, Ph.D.
}

Original Source: J.T.A.H. Volume 4 (2017/2018), Article A, pp. v - vi; online 27 September 2018

Recommended Citation: Williams, Ph.D., Thomas J.; "Appendix to Cover Art, The Journal of Texas Archeology and History Volume 4 (2017/2018): A Visual Guide to the Archaic Points Found at the Gault Site (41BL323) with Clovis Points for Comparison", (2018), Journal of Texas Archeology and History Volume 4 (2017/2018), pp. v - vi.

Copyright $(\subseteq) 2018$ by Journal of Texas Archeology and History.org, Inc. All rights reserved. Online/Digital publication: ISSN 2334-1874

The online, digital, and print versions of the publication "Journal of Texas Archeology and History" are published by Journal of Texas Archeology and History.org, Inc., a Texas nonprofit IRC Section 501(c)(3) corporation.

Reproduction, posting, transmission, or other distribution or use of the Journal volume, individual article or any portion of the material therein, in any medium, is permitted strictly for personal, non-commercial purposes via a personal-use exemption under a Creative Commons license granted by JTAH.org, Inc. This license exemption requires, as a condition of its granted permission, proper credit be attributed to JTAH.org as copyright holder (e.g., Journal of Texas Archeology and History.org (C) 2018). No part of this publication may be reproduced, posted, transmitted, or otherwise utilized or distributed in any form by any means or method for commercial purposes without the express written consent of the Publisher. Inquiries should be addressed to JTAH Publisher, Suite 307, Box 361, 5114 Balcones Woods Drive, Austin, Texas, 78759.

The Journal of Texas Archeology and History.org is an organization dedicated to furthering research, education and public outreach in the fields of archeology and history concerning Texas and its bordering states of Louisiana, Arkansas, Oklahoma, New Mexico and Northern Mexico; a region we call the "Texas Borderlands." The J.T.A.H. is collaborating with the Index of Texas Archaeology and S.F.A.S.U. to distribute their publication library to the general public via free and open-access channels. Visit www.JTAH.org to submit an article. 


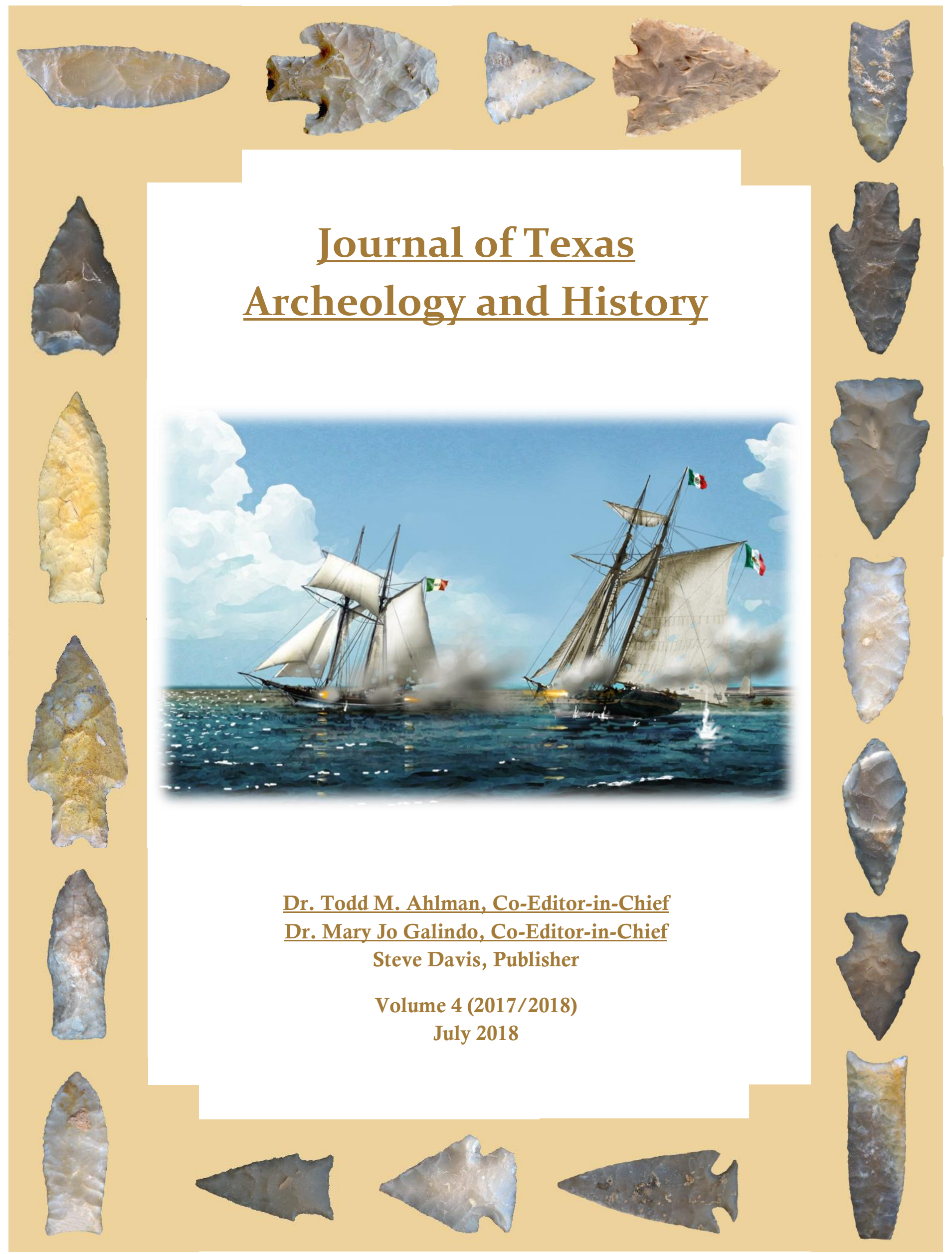




\title{
THE JOURnal OF TEXaS ARCHEOLOGY AND HISTORY
}

Volume $4(2017 / 2018)$

\author{
Dr. Todd M. Ahlman, Co-Editor-in-Chief \\ Dr. Mary Jo Galindo, Co-Editor-in-Chief \\ Steve Davis, Publisher
}

\author{
Published \\ by the \\ Journal of Texas Archeology and History.org, Inc. \\ Austin, Texas \\ July 2018
}


Copyright $(2018$ by Journal of Texas Archeology and History.org, Inc.

All rights reserved.

Online/Digital publication: ISSN 2334-1874

Domestic print and Kindle publication: ISBN 1725915308

International print publication: ISBN 978-1725915305

The online and print versions of the publication "Journal of Texas Archeology and History" are published by

Journal of Texas Archeology and History.org, Inc., a Texas nonprofit IRC Section 501(c)(3) corporation.

Reproduction, posting, transmission, or other distribution or use of the Journal volume, individual article or any portion of the material therein, in any medium, is permitted strictly for personal, noncommercial purposes by a personal-use exemption under a Creative Commons license granted by JTAH.org, Inc. This exemption requires, as a condition of granted permission, proper credit to JTAH.org as copyright holder (e.g., Journal of Texas Archeology and History.org (c) 2018).

No part of this publication may be reproduced, posted, transmitted or otherwise utilized or distributed in any form by any means or method for commercial purposes without the express written consent of the Publisher. Inquiries should be addressed to JTAH Publisher, Suite 307, Box 361, 5114 Balcones Woods Drive, Austin, Texas, 78759 or via email to Steve.Davis@JTAH.org.

The cover art border design gracing Volume 4 features a representative sampling of archaic and Clovis projectile points from the Gault site which spans the entire human occupation of North America. Included in the border art are four 3-D renderings of Clovis points (at the corners) that were imaged by Dr. Robert "Zac" Selden and 2-D images of archaic points by Antonio Arcudi. They are in alphabetical order beginning in the upper left. For a description of each of the projectile points, refer to the article titled "A Visual Guide to the Archaic Points Found at the Gault Site (41BL323) with Clovis Points for Comparison" by Dr. Tom Williams on page xi or, inclusively, click on the image of interest. This is the first in a series of special cover designs for the JTAH by the talented team at the Gault School of Archaeological Research at Texas State University. Future covers may highlight subjects such as the Andice point collection, Folsom points, and the "older than Clovis" tool kit. On this cover, we encourage you to click the various images for "extra" content and click here for an appendix describing all of the points shown.

On the front cover, center panel: the painting featured on the front cover is Figure 9, page 19 from Article 1: Chasing the Phantom Ship: Revisiting Interpretations of the Boca Chica No. 2 Shipwreck on the Texas Coast. The scene illustrating the engagement off Brazos Santiago, April 3, 1836 is entitled "Invincible vs. Bravo". This artwork was created especially for the Amy Borgens article by Peter Rindlisbacher (2017). 


\title{
A VISUAL GUIDE TO THE ARCHAIC POINTS FOUND AT THE GAULT SITE (41BL323) WITH CLOVIS POINTS FOR COMPARISON
}

\author{
Thomas J. Williams, Ph.D.
}

Archaeological excavations at the Gault Archaeological Site (41BL323) have revealed an almost complete stratigraphic record of the prehistoric occupation of Central Texas (Collins 2002, 2004). Furthermore, ages obtained from Area 15 of the site confirms good stratigraphic agreement between the diagnostic artifacts, cultural horizons, and stratigraphic units (Rodrigues, et al. 2016; Williams, et al. 2018). This includes some of the earliest evidence for a projectile point technology in North America (Williams, et al. 2018). Like many areas in Central Texas, the combination of water, raw materials, and its position along the Balcones Escarpment provided abundant resources essential to survival.

The Gault Archaeological Site has a long history. The site takes its name from a previous landowner, Henry Gault, and the first scientific excavations were conducted there in 1929 under the supervision of J. E. Pearce. In 1990, David Olmstead reported a unique find; an Alibates Clovis point sandwiched between two limestone plaques with engraved geometric designs. This led to a site visit by Dr. Tom Hester and Dr. Michael Collins. This finding was followed in 1997 by the discovery of an extremely fragile mandible of a juvenile mammoth by the Lindsey family. These discoveries prompted the recent archaeological excavations at the site, which began in 1999 and lasted until 2002. As many archaeologists will attest, the most interesting findings came at the very end of the 2002 field season, when archaeologist Sam Gardner exposed cultural material stratigraphically below Clovis in a small test unit. This led to negotiations between Michael Collins and the Lindsey family that resulted in the purchase of the property by Dr. Collins and its donation to the Archaeological Conservancy. Between 2007-2014, Area 15 was excavated to expose the cultural materials below. With the cessation of excavations in 2014, research focuses on reporting these findings and how this early archaeological assemblage in Central Texas is redefining the search for the earliest human occupants of the Americas.

The front cover of this issue of the Journal of Texas Archeology and History highlights two specific chronological periods in Texas. Firstly, in each corner you will find interactive 3D scans of four Clovis points that have been recovered from the site (Seldon et al. 2018). In between these, you will find and array of Archaic projectile points that have been recovered from the various excavations conducted between 1999-2002 and 2007-2014. This includes Early Archaic points such as the Hoxie and Martindale; Middle Archaic points including, Kinney and Nolan; and Late Archaic points including Pedernales, Marshall, and Bulverde. Clovis artifacts including, projectile points, blade cores, and diagnostic debitage have been recovered from a total of 9 excavation areas.

We will expand on these covers in the future to cover specific research projects currently being undertaken by the Gault School of Archaeological Research staff. The Gault School of Archaeological Research is a non-profit, 501(C)3 charitable organization dedicated to innovative, interdisciplinary research archaeology and education focusing on the earliest peoples in the western hemisphere and their cultural antecedents. The reader is encouraged to "click" around on the various cover images comprising the front and back cover border artwork to find and explore the additional rich content 
hidden there. Click here to open or download an informative "Appendix to the Cover Art containing this article, descriptive attribute data and a larger image of all projectile points shown on the front and back covers.

\section{ACKNOWLEDGEMENTS}

Sincere thanks go to Dr. Michael B. Collins, Dr. D. Clark Wernecke, and Nancy Velchoff at the Gault School of Archaeological Research. As some readers may well be aware, Texas projectile point typologies can divide opinion and every effort has been made to provide appropriate references. All of the types here were identified by Elton R. Prewitt, Dr. Robert Lassen, and Sergio Ayala as part of an ongoing analysis of the archaeological materials recovered from the Gault Site. Excavations at the Gault Site were funded in part by NSF Grant 0920549 to Texas State University, San arcos. The Gault School of Archaeological Research is funded with the generosity of private donors.

To learn more about the Gault Archaeological Site click here.

To find out about Dr. Zac Selden's work at the Center for Regional Heritage Research click here.

To find out about the important research and working with the Gault School of Archaeological Research click here.

Text: Thomas J. Williams, Ph.D.

3-D Interactive Imaging: Robert Z. Selden, Jr., Ph.D.

Cover Border Artwork Images: Antonio Arcudi, Sergio, and Thomas J. Williams, PhD.

Central Texas Chronology sheets: Thomas J. Williams, Ph.D., text by Antonio Arcudi.

Border Art Cover Design and Layout: Steve Davis.

\section{REFERENCES CITED}

Collins, Michael B.

2002 The Gault Site, Texas, and Clovis Research. Athena Review 3(2):31-42.

2004 Archaeology in Central Texas, edited by T. K. Perttula, pp. 101-126. Texas A\&M University Press, College Station, Texas.

Rodrigues, K., W. J. Rink, Michael B. Collins, T. J. Williams, A. Keen-Zebert and G. I. López

2016 OSL ages of the Clovis, Late Paleoindian, and Archaic components at Area 15 of the Gault Site, Central Texas, U.S.A. Journal of Archaeological Science: Reports 7:94-103.

Selden, Robert Z. Jr.; Williams, Thomas J.; Velchoff, Nancy; and Collins, Michael B.

2018 3D Scan Data for Selected Clovis-Age Artifacts from the Gault Site (41BL323), CRHR Research Reports: Vol. 4 , Article 1.

Williams, Thomas J., Michael B. Collins, Kathleen Rodrigues, William Jack Rink, Nancy Velchoff, Amanda Keen-Zebert, Anastasia Gilmer, Charles D. Frederick, Sergio J. Ayala and Elton R. Prewitt 2018 Evidence of an early projectile point technology in North America at the Gault Site, Texas, USA. Science Advances 4(7):eaar5954. 


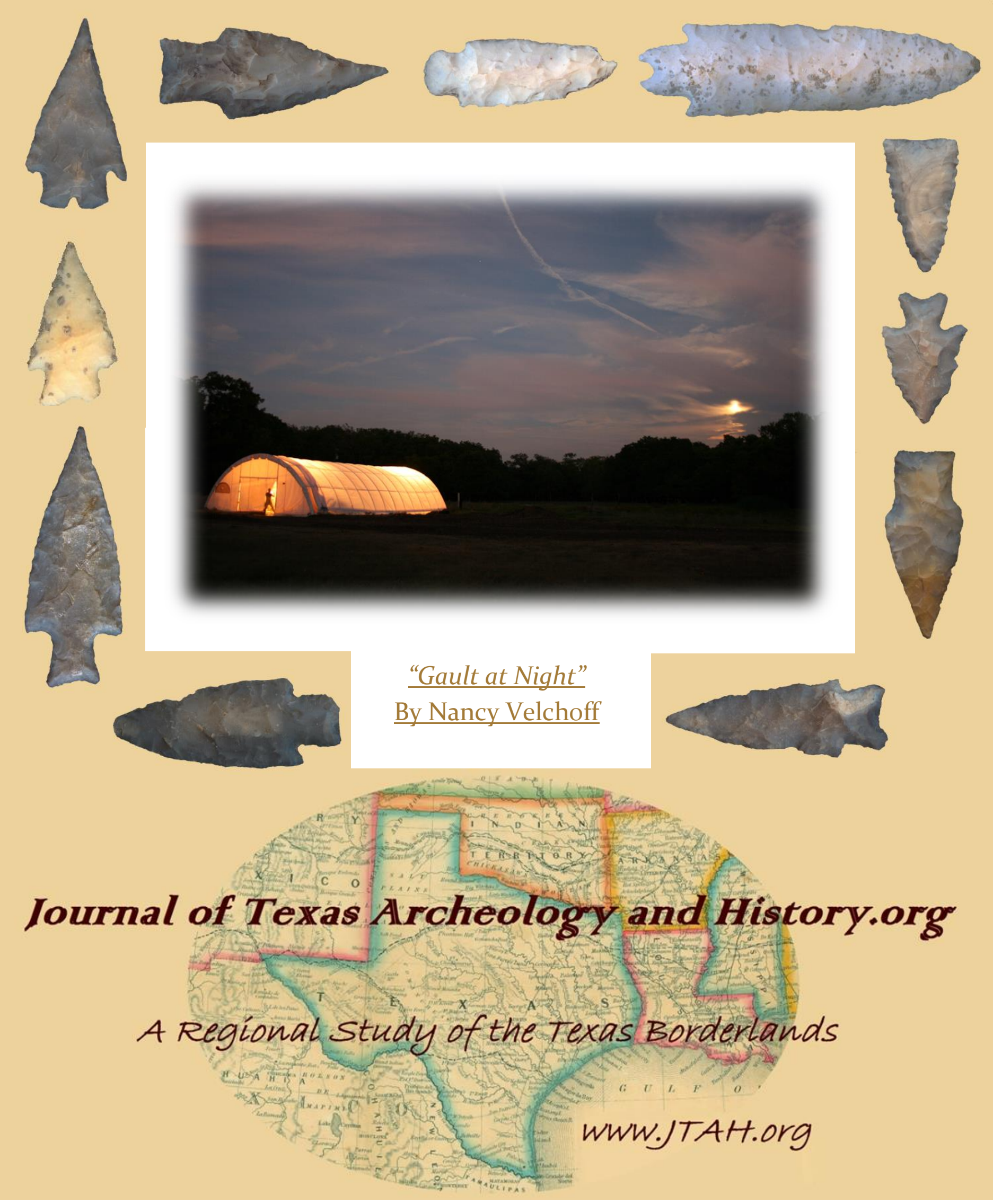

Journal of Texas Archeology and History.org, Inc.

Suite 307, Box 361

5114 Balcones Woods Drive

Austin, Texas 78759 